\title{
Rancang Bangun Sistem Informasi Rekam Medis Menggunakan Model Rapid Application Development (RAD)
}

\author{
Muhammad Amin ${ }^{* 1}$, Maskur ${ }^{2}$, Wildan Suharso ${ }^{3}$ \\ 1,2,3 Teknik Informatika/Muhammadiyah Malang \\ maskur@umm.ac.id ${ }^{* 1}$, muhammadamin353@gmail.com², w.suharso@umm.ac.id ${ }^{3}$
}

\begin{abstract}
Abstrak
Sistem rekam medis Rumah Sakit Wijaya Kusuma Lumajang digunakan untuk mengelola data rekam medis yang meliputi data pendaftaran dan data medis pasien. Dimana sistem rekam medis yang digunakan ada saat itu sudah tidak sesuai dengan kebutuhan petugas rekam medis saat ini, sehingga dibuatkan sistem yang baru khusus bagian rekam medis yang sesuai dengan kebutuhan petugas rekam medis dengan cara menambahkan dokumen elisitasi agar supaya sesuai dengan kebutuhan petugas rekam medis. Sistem tersebut berbasis website dengan menggunakan model pengembangan perangkat lunak Rapid Application Development (RAD) dengan adanya penambahan fitur perhitungan rekam medis otomatis yang dulunya perhitungan tersebut dilakukan secara manual, fitur untuk menampilkan diagram rekam medis, dan fitur kode ICD10 dan ICD 9 yang lebih lengkap sesuai dengan buku kamus besar kode rekam medis. Pengujian sistem rekam medis ini nantinya akan di uji dengan menggunakan pengujian Blackbox Testing dan pengujian User Acceptance Test (UAT). Sistem rekam medis yang dibuat dan kembangkan sudah digunakan pihak bagian rekam medis rumah sakit sampai saat ini.
\end{abstract}

Kata Kunci: Sistem Rekam Medis, Rapid Application Development, User Acceptance Test

\begin{abstract}
Hospital medical record system Wijaya Kusuma Lumajang is used to manage medical record data including registration data and medical data of patient. Where the medical record system used there at that time was not in accordance with the needs of the current medical record officer, so created a new system specifically the medical record in accordance with the needs of medical record officers by adding elicitation documents to fit the needs of medical record staff. The system is based on a website using Rapid Application Development (RAD) software development model with the addition of automatic medical record calculation feature which used to be done manually, feature to display medical record diagram, and feature ICD10 and ICD 9 code more complete accordingly with a large dictionary book of medical record codes. Testing of this medical record system will be tested by using Blackbox Testing test and User Acceptance Test (UAT). The medical record system developed and developed has been used by the hospital medical record to date.
\end{abstract}

Keywords: Medical Record System, Rapid Application Development, User Acceptance Test

\section{Pendahuluan}

Pengertian sistem informasi rekam medis adalah suatu serangkaian informasi data medis (medical record) yang meliputi pemeriksaan identitas, penyakit, serta tindakan medis yang dirancang dan dikelola untuk saling berkaitan untuk mencapai suatu kesatuan [1].

Rekam medis merupakan tentang catatan dan dokumen tentang identitas pasien, pemeriksaan, tindakan dan pelayanan lain yang telah diberikan kepada pasien. Rekam medis dapat diperoleh informasi tentang jenis penyakit, kondisi kesehatan pasien dan lain sebagainya [2]. Melalui rekam medis dokter juga dapat menentukan tindakan lanjut dalam upaya pelayanan pasien maupun tindakan medis berikutnya.

Selama ini pencatatan rekam medis di Rumah Sakit Wijaya Kusuma Lumajang sudah menggunakan sebuah program SIM RS berbasis web. SIM RS merupakan sebuah program sistem informasi management rumah sakit yang saling terhubung antara sub bagian-bagian yang ada di dalam rumah sakit. Program rekam medis Rumah Sakit Wijaya Kusuma Lumajang yang ada mengalami masalah, contohnya: sebagian fitur yang ada di dalam program tidak bisa digunakan, fitur diagnosa penyakit pasiennya yang masih kurang lengkap kode ICD 10 maupun 
kode ICD 9, fitur perhitungan rekam medis tidak ada, sistem pelaporannya tidak sesuai dengan standart pelaporan rekam medis.

Selain permasalahan diatas, masalah lain juga terjadi saat petugas membuat laporan bulanan kegiatan medis menggunakan MS. Excel dan melakukan penginputan data dalam program SIM RS yang ada, sehingga untuk mengerjakan 1 buah data dilakukan proses pengerjaan 2 kali kerja yaitu menginputkan kedalam MS. Excel dan program SIM RS. Jadi, proses pembuatan laporan tersebut membutuhkan waktu yang lama karena mereka melakukan inputan dengan 2 kali kerja dimulai dari inputan data ke dalam SIM RS dan inputan data kedalam MS. Excel untuk pembuatan laporan data bulanan yang benar yang sesuai dengan format data reelnya dan akan diserahkan ke pihak manajemen dalam bentuk hard copy. MS. Excel juga terjadi sebuah permasalahan yaitu tampilan atau user interface MS. Excel yang monoton, hanya bisa di akses pada satu unit komputer saja dan tidak bisa diakses oleh komputer lain kalau tidak memiliki soft copy datanya, serta data yang diinputkan tidak bisa dilihat oleh pihak manajemen secara real time.

Maka dari itu diharapkan sistem rekam medis eletronik ini petugas mendapat kemudahan dalam mencari data rekam medis pasien, tidak kesulitan dalam proses pembuatan laporan bulanan yang sesuai standar rekam medis untuk manajemen dan tidak membutuhkan waktu yang lama. Penerapan sistem tersebut diharapkan dapat mengatasi permasalahan yang ada dalam bagian rekam medis di Rumah Sakit Wijaya Kusuma Lumajang. Perancangan sistem rekam medis secara elektronik dalam bentuk program web lebih cocok menggunakan model pengembangan perangkat lunak RAD (Rapid Application Development) yang dapat membantu di dalam proses pengolahan data rekam medis pasien. Alasan peneliti memilih model pengembangan perangkat lunak RAD adalah proses pengerjaan sistem dapat menghemat waktu dan relatif cepat kurang lebih 3 bulan serta dapat menghemat biaya sebab sistem yang akan peneliti buat tidak terlalu besar seperti SIM RS yang mencakup semua bagian yang ada didalam rumah sakit [3].

Jurnal pendukung dari penelitian sebelumnya, sistem yang menggunakan metode pengembangan perangkat lunak RAD diantaranya: jurnal milik Muhammad Wardianto tahun 2011 dengan judul "rancang bangun aplikasi pendaftaran online jasa pengobatan berbasis multimedia pada klinik utama siti aksar depok" juga menggunakan metode RAD dan menghasilkan sebuah sistem berbasis web [4], jurnal milik Fuad Al Hasan Adi Prasetya tahun 2016 dengan judul "aplikasi pencarian tempat layanan kesehatan di kabupaten nganjuk pada perangkat mobile android berbasis lbs" juga menggunakan metode pengembangan RAD yang menghasilkan sistem andorid berbasis location based service (LBS) [5].

Berdasarkan permasalahan tersebut, diangkatlah sebuah topik penelitian dengan judul "Rancang Bangun Sistem Informasi Rekam Medis Rumah Sakit Menggunakan Model Pengembangan Perangkat Lunak Rapid Application Development (RAD)". Retribusi yang penulis lakukan pada penelitian ini adalah pembuatan sistem yang akan digunakan selamanya oleh pengguna sistem rekam medis untuk mempermudah pembuatan pelaporan bulanan yang sesuai dengan standart pelaporan bagian rekam medis rumah sakit.

\section{Metode penelitian}

Pengembangan pada sistem informasi rekam medis dilakukan dengan menggunakan model pengembangan Rapid Application Development (RAD) seperti pada Gambar 1.

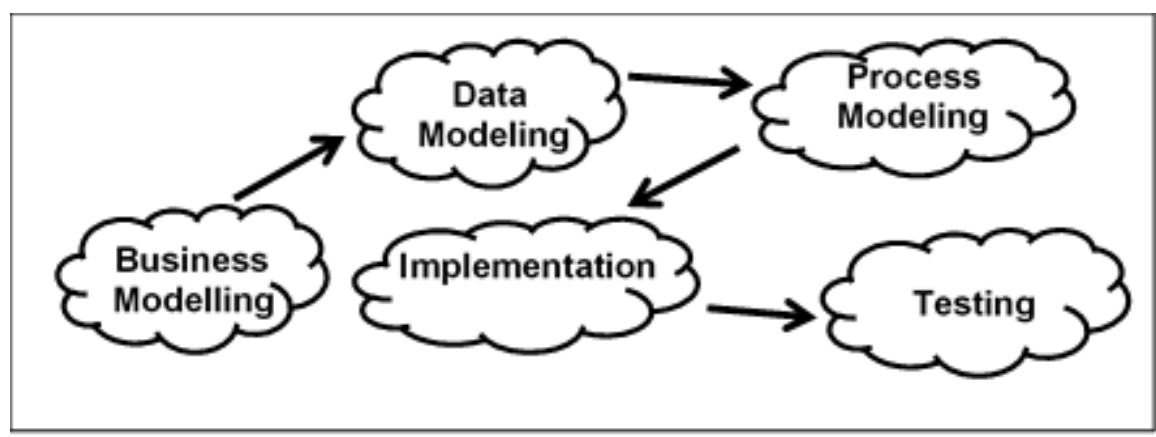

Gambar 1. Rapid Application Development (RAD)

REPOSITOR, Vol. 2, No. 2, Februari 2020: 137-144 
a. Bussiness Modelling

Dalam tahap ini yaitu mencari suatu aliran informasi tentang proses bisnis di dalam rekam medis dan infomasi apa yang harus di munculkan dalam proses bisnis kemudian siapa yang memproses rekam medis.

b. Data Modeling

Informasi yang sebagian dari fase bussiness modelling disaring ke dalam serangkaian objek data yang dibutuhkan untuk menopang bisnis rekam medis tersebut. Contoh reel dari proses data modelling ini adalah pada tahap pencatatan dokumen elisitasi yang sudah penulis lakukan secara langsung pada bagian rekam medis di Rumah Sakit Wijaya Kusuma Lumajang.

c. Process Modelling

Gambaran pemrosesan sistem rekam medis yang diciptakan untuk menambah, memodifikasi, menghapus, atau mendapatkan kembali sebuah objek data. Contohnya seperti desain usecase digaram, activity diagram, sequence diagram, class diagram serta gambaran desain interface mentahan (mookup) dari sistem yang akan dibuat [6].

d. Implementation

Implementasi atau sebuah tahap pemrograman (coding) dilakukan setelah hasil dari process modelling selesai serta di dalam tahapa implementasi terdapat komponen application generation atau disebut dengan istilah pemanfaatan kembali dari sebagian komponen program yang sudah ada untuk dipakai dan di kembangkan dalam proses bisnis alur kerjanya dalam sistem rekam medis tanpa memulai dari nol [7].

e. Testing

Pengujian semua komponen atau fitur dan interface sistem rekam medis yang dilatih secara penuh dan fungsional. Contoh reel pada proses ini adalah sistem yang sudah jadi akan diuji secara Metode Blackbox Testing dan User Acceptance Test (UAT).

\section{Hasil penelitian dan pembahasan}

\subsection{Business Modelling (Arsitektur Sistem)}

Secara umum deskripsi business modelling sistem dapat dijelaskan melalui arsitektur sistem yang dapat dilihat di Gambar 2.

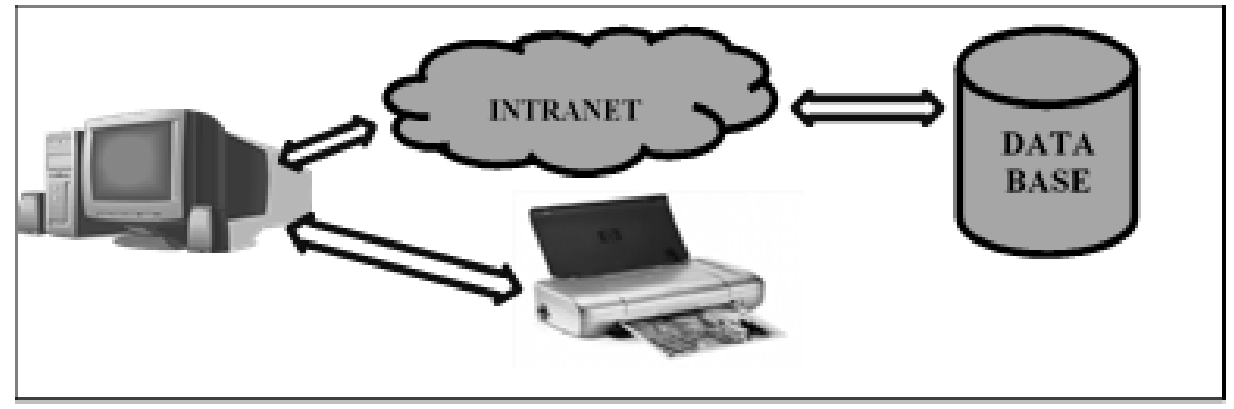

Gambar 2. Arsitektur Sistem

Pada Gambar 2. Arsitektur sistem merupakan desain alur kerja sistem, dimana aktifitas di dalam sistem dapat dilakukan melalui 1 komputer petugas yang terhubung ke intranet, data diolah dan terhubung dengan database. Sistem dapat melakukan pencetakan data. Proses kerja sistem 4 bagian penting, diantaranya :

a. Komputer

Inputan data merupakan perintah yang berfungsi untuk memasukan data seperti biasanya menggunakan fitur keyboard.

b. Intranet

Intranet disini maksudnya untuk sebuah jaringan lokal yang berada dalam 1 perangkat komputer untuk mengaplikasikan sebuah sistem rekam medis tersebut. Sistem akan memproses parameter dan query tersebut untuk diteruskan ke server melalui PHP, dengan memanfaatkan layangan fasilitas aplikasi xampp untuk menghubungkan dengan database.

c. Database Server

Database Server merupakan bagian yang berfungsi sebagai database atau media penyimpanan data Sistem Rekam Medis. 


\section{d. Printer}

Printer merupakan alat untuk mencetak hasil laporan dari semua proses data yang sudah dilakukan di dalam Sistem Rekam Medis.

\subsection{Data Modelling (Elisitasi Kebutuhan)}

Elisitasi kebutuhan merupakan serangkaian kegiatan yang untuk menggali kebutuhan suatu sistem melalui komunikasi dengan pengguna sistem. Berikut Tabel 1. merupakan hasil dari elisitasi serta lembar persetujuan dokumen elisitasi yang sudah penulis lakukan dengan pengguna rekam medis secara langsung.

Tabel 1. Elisitasi Kebutuhan

\begin{tabular}{cl}
\multicolumn{1}{c}{ Tabel 1. Elisitasi Kebutuhan } \\
\hline \multicolumn{1}{c}{ FUNCTIONAL } \\
\hline \multicolumn{1}{c}{ ANALISA KEBUTUHAN } \\
& \multicolumn{1}{c}{ Saya ingin sistem dapat: } \\
1 & Menampilkan halaman login \\
2 & Menampilkan Home (Pendaftaran dan Rekam Medis) \\
3 & Menampilkan form halaman pendaftaran pasien \\
4 & Menampilkan form inputan data diri pasien (identitas pasien) \\
5 & Menampilkan inputan data pasien yang berisi : Status pasien (PL/PB), Jenis \\
& $\begin{array}{l}\text { perawatan (RJ/RI), Kategori pasien (BPJS, Karyawan, Umum,dll), Nomor yang bisa } \\
\text { dihubungi }\end{array}$ \\
\hline
\end{tabular}

\subsection{Process Modelling}

Pada tahap ini menjabarkan tentang desain dari sistem yang akan dikembangkan dengan melakukan pemodelan.

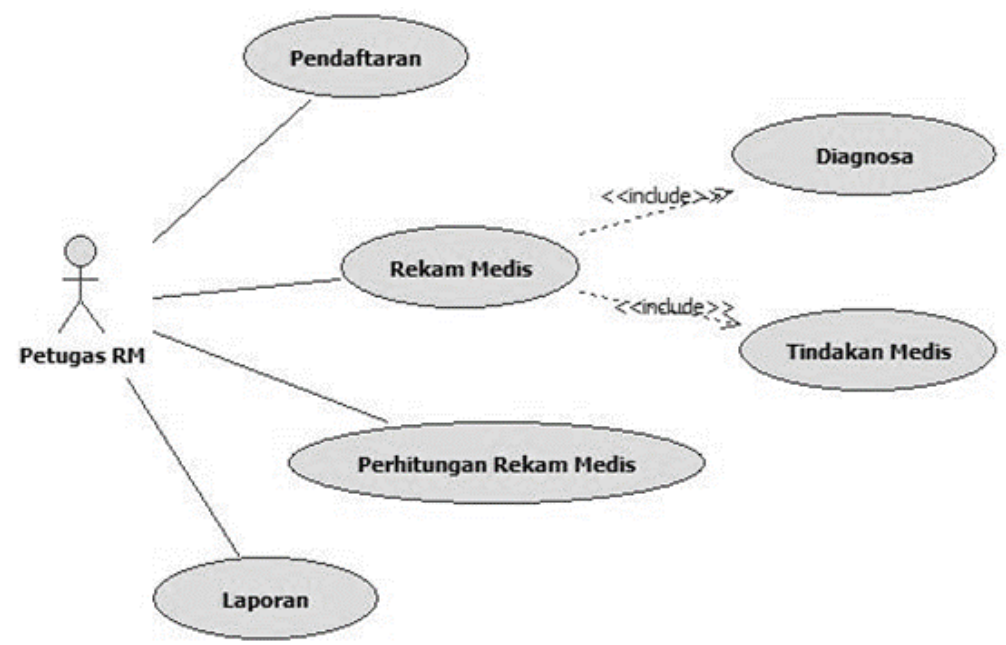

Gambar 3. Usecase Diagram Sistem Rekam Medis

Pada Gambar 3. adalah usecase diagram dari sistem rekam medis yang akan dibangun dan pada Tabel 2. penjelasan dari usecase tersebut.

Tabel 2. Spesifikasi Usecase Diagram Sistem Rekam Medis

\begin{tabular}{ccl}
\hline Aktor & Usecase & \multicolumn{1}{c}{ Keterangan } \\
\hline & Pendaftaran & $\begin{array}{l}\text { Petugas RM menginputkan data pasien yang sudah } \\
\text { mendaftar } \\
\text { Setelah Petugas RM melakukan input data pendaftaran } \\
\text { Petugas } \\
\text { RM }\end{array}$ \\
& Rekam Medis & $\begin{array}{l}\text { pasien, Petugas RM melakukan input data rekam medis } \\
\text { pasien yang meliputi data-data medis pasien }\end{array}$ \\
& $\begin{array}{c}\text { Perhitungan } \\
\text { Rekam Medis } \\
\text { Laporan }\end{array}$ & $\begin{array}{l}\text { Perhitungan-perhitungan khusus di dalam rekam medis } \\
\text { Fitur laporan yang sesuai dengan format rekam medis }\end{array}$ \\
\hline
\end{tabular}

REPOSITOR, Vol. 2, No. 2, Februari 2020: 137-144 


\subsection{Implementation}

Setelah melakukan process modelling, tahap selanjutnya adalah pemrograman atau implementasi atau pemrograman dari hasil process modelling yang sudah dilakukan sebelumnya. Proses hasil implementasi tsistem informasi rekam medis dapat dilihat pada Gambar 4.

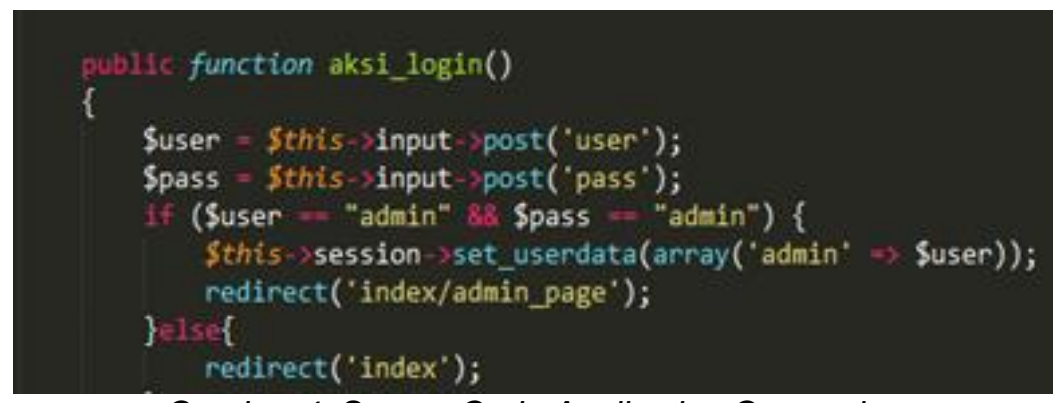

Gambar 4. Source Code Application Generation

Pada Gambar 4. Merupakan source code application generation dari program ci standart kemudian dikembangkan lagi menjadi sebuah sistem rekam medis yang hanya di ambil dari template ci saja dan pada Gambar 5 merupakan hasil dari pengembangannya.

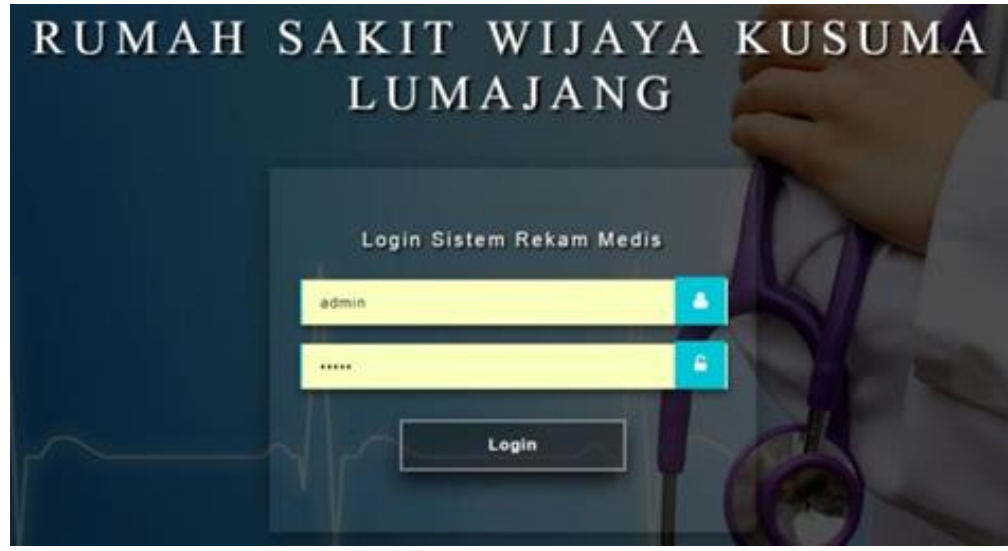

Gambar 5. Tampilan Halawan Awal Sistem Rekam Medis

Pada Gambar 5 merupakan hasil dari pengembangan application generation rekam medis terhadap program ci.

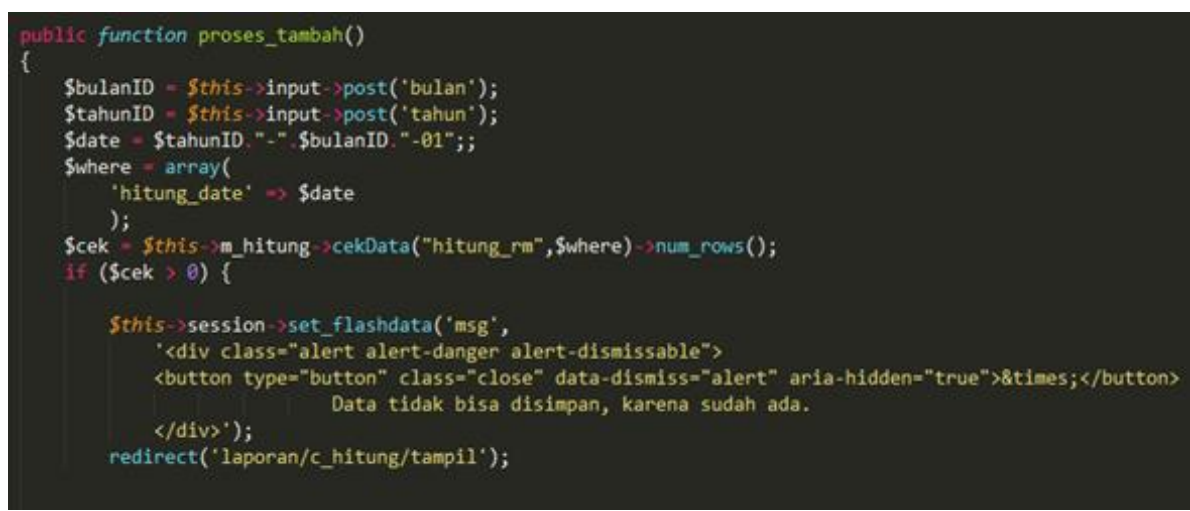

Gambar 6. Source Code Perhitungan Rekam Medis

Pada Gambar 6 merupakan source code dari perhitungan rekam medis yang selalu dilakukan secara otomatis dari sistem ketika petugas rekam medis memilih bulan dan tahun yang akan dihitung dan Gambar 7, Gambar 8, dan Gambar 9 di bawah ini adalah hasil dari source code yang di proses oleh sistem. 

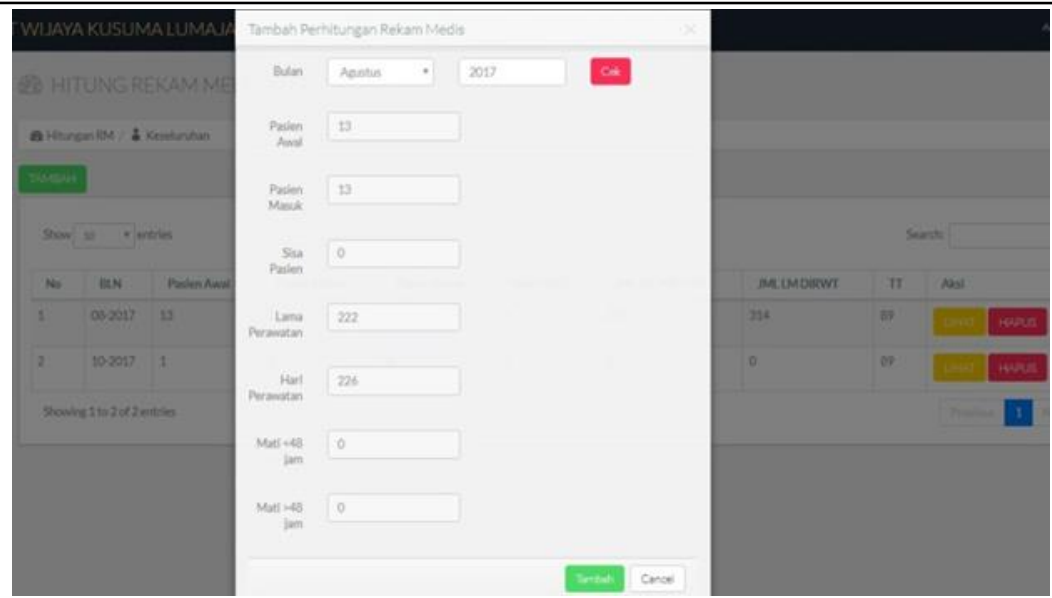

Gambar 7. Tampilan Perhitungan Rekam Medis
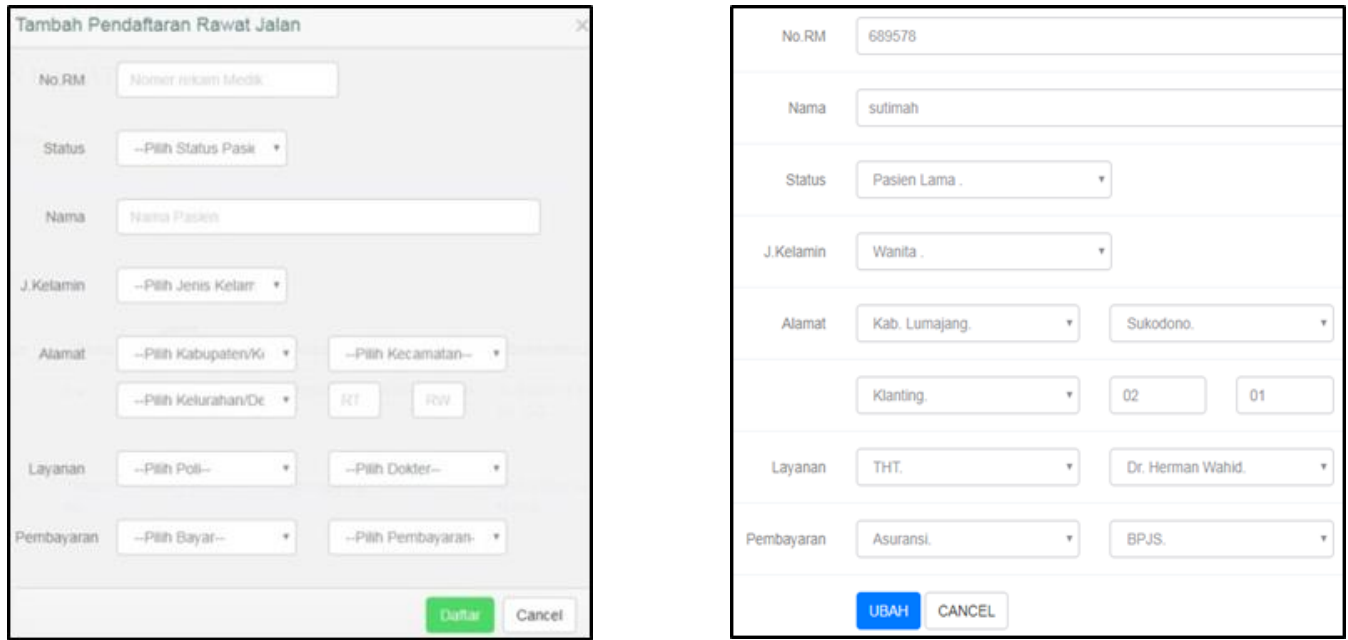

Gambar 8. Tampilan Management Pendaftaran Rawat Jalan
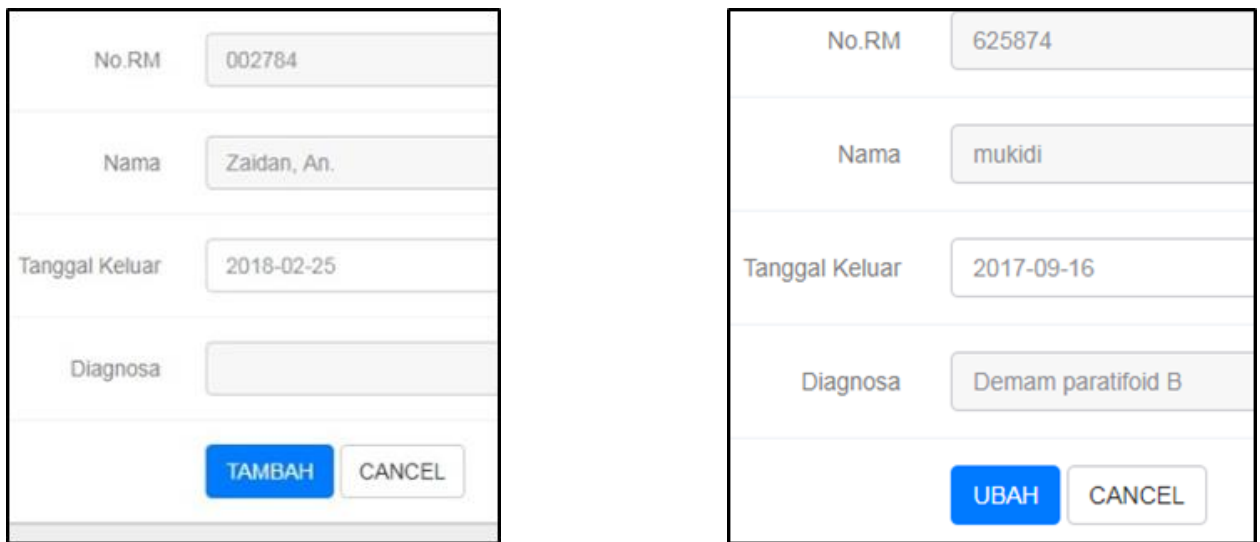

Gambar 9. Tampilan Management Rekam Medis Rawat Jalan

\subsection{Testing (Pengujian)}

Pengujian dilakukan dengan menggunakan 2 metode yaitu metode Blackbox Testing dan metode User Acceptance Test (UAT). Pengertian dari pengujian Blackbox yaitu sebuah pengujian sistem perangkat lunak yang dilakukan pada struktur komponen sistem secara manual atau otomatis [8]. Sedangkan pengertian dari pengujian User Acceptance Test (UAT) adalah pengujian yang dilakukan untuk menguji tingkat kesesuainnya dan kehandalannya sebagai syarat untuk diterima oleh pengguna sistem [9]. 
Hasil pengujian Blackbox Testing dapat dilihat pada Tabel 3. Kemudian hasil pengujian User Acceptance Test (UAT) dapat dilihat di Tabel 4, secara detai dapat dilihat dibawah ini.

Tabel 3. Hasil Pengujian Blackbox

\begin{tabular}{cccc}
\hline No. & $\begin{array}{c}\text { Jenis } \\
\text { pengujian }\end{array}$ & Hasil yang diharapkan & $\begin{array}{c}\text { Hasil } \\
\text { pengujian }\end{array}$ \\
\hline 1. & $\begin{array}{c}\text { Tambah data } \\
\text { pendaftaran } \\
\text { rawat inap } \\
\text { Tambah data } \\
\text { rekam medis } \\
\text { rawat inap }\end{array}$ & Interface form tambah data pendaftaran & Berhasil \\
rawat inap & $\begin{array}{c}\text { rawat inap } \\
\text { Tambah data }\end{array}$ & Berhasil \\
3. & $\begin{array}{c}\text { perhitungan } \\
\text { keseluruhan }\end{array}$ & Interface form tambah data perhitungan \\
keseluruhan & Berhasil \\
4. & $\begin{array}{c}\text { Tambah data } \\
\text { poli }\end{array}$ & Interface form tambah data poli & Berhasil \\
5. & $\begin{array}{c}\text { Tambah data } \\
\text { dokter }\end{array}$ & Interface form ubah data dokter & Berhasil \\
6. & $\begin{array}{c}\text { Cek Laporan } \\
\text { rawat jalan }\end{array}$ & Interface form cek laporan rawat jalan & Berhasil \\
\hline
\end{tabular}

Tabel 4. Pengujian User Acceptance Test

\begin{tabular}{|c|c|c|c|c|c|c|}
\hline No. & $\begin{array}{l}\text { Deskripsi } \\
\text { Pengujian }\end{array}$ & $\begin{array}{l}\text { Prosedur } \\
\text { Pengujian }\end{array}$ & $\begin{array}{c}\text { Data } \\
\text { Masukan }\end{array}$ & $\begin{array}{l}\text { Keluaran yg } \\
\text { Diharapkan }\end{array}$ & $\begin{array}{l}\text { Hasil yg } \\
\text { Didapat }\end{array}$ & $\begin{array}{l}\text { Hasil uji } \\
\text { Diterima }\end{array}$ \\
\hline 1. & $\begin{array}{l}\text { Perhitungan } \\
\text { keseluruhan }\end{array}$ & $\begin{array}{l}\text { - Tekan menu } \\
\text { perhitungan } \\
\text { keseluruhan } \\
\text { Tambah data } \\
\text { - Pilih \& klik } \\
\text { tambah } \\
\text { - Pilih bulan dan } \\
\text { tahun berapa } \\
\text { yang akan } \\
\text { dihitung } \\
\text { - Klik cek } \\
\text { - Pilih \& klik } \\
\text { tambah }\end{array}$ & & $\begin{array}{c}\text { Tambah data } \\
\text { perhitungan } \\
\text { keseluruhan } \\
\text { berhasil }\end{array}$ & Berhasi & $\checkmark$ \\
\hline 2. & $\begin{array}{c}\text { Perhitungan } \\
\text { peruangan }\end{array}$ & $\begin{array}{l}\text { - Tekan menu } \\
\text { perhitungan } \\
\text { peruangan } \\
\text { Tambah data } \\
\text { - Pilih \& klik } \\
\text { tambah } \\
\text { - Pilih bulan dan } \\
\text { tahun berapa } \\
\text { yang akan } \\
\text { dihitung } \\
\text { - Klik cek } \\
\text { - Pilih kamar } \\
\text { yang ingin } \\
\text { dihitung } \\
\text { - Klik cek } \\
\text { perhitungan } \\
\text { - Pilih \& klik } \\
\text { tambah }\end{array}$ & & $\begin{array}{c}\text { Tambah data } \\
\text { perhitungan } \\
\text { peruangan } \\
\text { berhasil }\end{array}$ & Berhasi & $\checkmark$ \\
\hline
\end{tabular}




\section{Kesimpulan}

Dalam penelitian ini aplikasi sistem rekam medis berbasis Web ini dapat memudahkan bagian admin rekam medis untuk mengelola data dan informasi data rekam medis pasien maupun data identitas pasien yang sesuai dengan kebutuhan mereka dan aplikasi ini sudah digunakan oleh pengguna selama kurang lebih 4 bulan sebelum penulis melakukan sidang tugas akhir.

Dengan aplikasi Aplikasi sistem rekam medis berbasis Web ini dapat meminimalisir kesalahan-kesalahan yang bisa saja terjadi pada sistem yang sudah berjalan terutama dalam hal perhitungan data rekam medis. Maka dari itu sistem tersebut ditambahkan sebuah fitur perhitungan keseluruhan dan perhitungan peruangan agar supaya perhitungan bisa dilihat lebih detail dan terperinci. Serta adanya penambahan fitur kode ICD 9 dan ICD 10 berfungsi untuk memudahkan admin dalam mencari kode-kode rekam medis dalam bentuk sistem tanpa harus melihat dari kamus buku besar kode rekam medis.

\section{Referensi}

[1] Fatimah Haniyah. 2009. Pengembangan Sistem Informasi Rekam Medis Menggunakan Model Prototyping. Universitas Indonesia.

[2] Ahmad Id Hilmi. 2008. Pengembangan Sistem Informasi Rawat Jalan Berbasis Rekam Medis Di RSU Kota Sabang. Universitas Indonesia.

[3] Safrian Aswati, M. Sabir Ramadhan, Ada Udi Firmansyah, Khairil Anwar. 2017. Studi Analisis Model Rapid Application Development Dalam Pengembangan Sistem Informasi. STMIK Royal. Sumatera Utara.

[4] Muhammad Wardianto. 2011. Rancang Bangun Aplikasi Pendaftaran Online Jasa Pengobatan Berbasis Multimedia Pada Klinik Utama Siti Aksar Depok. Universitas Negeri Syarif Hidayatullah. Jakarta.

[5] Fuad Al Hasan Adi Prasetya. 2016. Aplikasi Pencarian Tempat Layanan Kesehatan di Kabupaten Nganjuk Pada Perangkat Mobile Android Berbasis LBS. Universitas Nusantara Persatuan Guru Republik Indonesia. Kediri.

[6] Riani Eka Sari. 2015. Sistem Informasi Administrasi Pasien Rawat Jalan dan Rawat Inap Berbasis Web Pada Puskesmas Tanjung Raja. Universitas Islam Negeri Raden Fatah. Palembang.

[7] Anofrizen, Alfi Fadlan. 2015. Mobile Application Pembelajaran Interaktif Bahasa Inggris Berbasis Android Menggunakan Metode Rapid Application Development (RAD). UIN Sultan Syarif Kasim. Riau.

[8] Suci Putri Herizona. 2015. Rancang Bangun Aplikasi Pelayanan Rumah Sakit. Universitas Islam Negeri Hidayatullah. Jakarta.

[9] Ikhsan Anugerah, Utami Dewi Widianti. 2014. Pembangunan Sistem Informasi Supply

[10] Chain Management Di CV Cihanjuang Inti Teknik Divisi Minuman Tradisional. Universitas Komputer Indonesia. Bandung. 